\title{
METHODOLOGY FOR INVESTMENT EVALUATION IN ELECTRICITY GENERATION MODULES ACCORDING TO THE REQUIREMENTS OF THE EUROPEAN UNION
}

\author{
L. Vempere' ${ }^{1}$ A. Jasevics ${ }^{1}$, L. Zemite ${ }^{1}$, G. Vempers ${ }^{2}$ \\ ${ }^{1}$ Riga Technical University, \\ Faculty of Electrical and Environmental Engineering, \\ Institute of Power Engineering \\ 12-1 Azenes Str., Riga, LV-1048, LATVIA \\ *e-mail: laila.zemite@rtu.Iv \\ ${ }^{2}$ Inženierija Ltd, \\ 42 Brivibas Str., Ogre, LV-5001, LATVIA \\ *e-mail: info@inzenierija.Iv
}

For a country to be able to survive successfully, one of the criteria is a stable electric power supply that meets certain technical parameters. In the European Union, several countries are working synchronously to ensure the safety of electricity systems. In order to achieve such synchronous operation, the European Union has adopted Regulation No. 2016/631, which sets out the requirements for grid-connected generators. The present article develops a model to assess the compliance of generators with the requirements of the Regulation, as well as conducts economic analysis to assess which generators need investment and whether their use will provide economic benefits. In this way, the state can create a priority list, where generators are divided according to their socio-economic benefits. In 2025, the Baltic States plan to become integrated into the Energy Systems Association of Continental Europe and work synchronously with the other European Union countries, disconnected from the current BRELL energy systems. Therefore, the model developed in the article is applied to the case of Latvia to determine the necessary investments, as a result of which alternatives are considered for improving the current situation.

Keywords: Cost-benefit analysis, generating sources, investments, power plants, synchronisation. 
Electric power supply is a common national infrastructure system whose parameters must be consistent with the overall economic needs and technical characteristics. Any changes in the external environment or system must be avoided in order to ensure the equilibrium of the system. The functioning of several national energy systems in synchronous mode significantly reduces the costs of operating the energy system and improves overall system safety by reducing the potential adverse effects of local accidents on the stability of the energy system as well as simplifying the maintenance of essential performance parameters of the energy system, such as frequency. In order for the system to operate smoothly, it is necessary to ensure a continuous balance of the electricity produced and consumed, including in emergency situations. Deviation from this balance causes the system to be unbalanced. Electricity balance is characterised by electricity frequency.

The Commission of the European Union (EU) has adopted Regulation No. 2016/631, which establishes a network code on the applicable network connection requirements for generators. The purpose of the application of the requirements is the safety of electricity systems in the European Union (continuous consumer energy supply), including limiting frequency fluctuations at the level allowed for the system, as well as the development of the electricity and ancillary services market and the development of renewable energy sources. The legal provisions of the EU Network Connections Code do not apply to existing electrical equipment, but it provides for a mechanism to apply those legal provisions to existing electrical equipment in the event of significant changes in the energy system
[1], [2]. In cases when the changes are so large that power plants which do not comply with the requirements of the Regulation cannot meet the objectives set out in the Regulation, regulation on the modernisation of existing plants may be adopted, which means additional investment.

In the event that production plants do not fully or partly comply with the requirements of the system, a study on the feasibility of their application and the amount of investment needed must be carried out. The amount of investment is to be assessed from the point of view of the common system and individual suppliers. On the other hand, from an economic point of view, it is necessary to assess losses arising from nonrealisation of investment [3], [4]. Without investment, losses are suffered by society, business, and the economy as a whole, not just regarding the amount of electricity not delivered. As a result, these losses need to be calibrated.

The Baltic power supply system is designed to be closely linked to the energy supply infrastructure of neighbouring countries. Historically, the energy systems of Latvia and the other Baltic States have been designed as part of the former USSR unified energy system, in the so-called BRELL energy systems (the energy systems of Belarus, Russia, Estonia, Latvia, and Lithuania), so the Baltic States also maintained the historical electricity infrastructure connections with Russia and Belarus after the restoration of independence in 1991 [5][7]. As the Baltic States joined the European Union (EU) and closer links to the EU's energy bloc were established in 2007, the idea was that the Baltic States could work in sync with the rest of the EU. Exploration work began in 2013 to determine the 
provisional works and the costs of synchronisation. In 2015, a synchronisation road map was approved, and the Baltic States launched a process of preparations for synchronisation with the EU, scheduled for 2025 [8]. On 27 May 2019, the agreement on connecting the electricity systems of the Baltic States to the continental European grid entered into force. On 20 June 2019, in Brussels, the prime ministers of Lithuania, Estonia, and Poland signed a political road map for connecting the electricity systems of the Baltic States to the continental European grid. At the moment, disconnection from BRELL in the energy circle is taking place. Consequently, in the event of such a cut-off, the continued supply of electricity to consumers is problematic as regards the quality requirements [9]. At present, in the Baltic (2020) normal operating mode, the frequency must be between 49.95 and $50.05 \mathrm{~Hz}$ [10]. The energy systems of the Baltic States are facing a major challenge to successfully integrate into the Energy Systems Association of Continental Europe. All transmission system operators within the Energy Systems Association have to jointly ensure electricity balance through frequency adjustment services [11].

Given the need for the EU countries to carry out an analysis of the application of the Regulation for existing modules to assess the overall operation of the system in emergency situations, including frequency provision, the smaller investments are assessed in a situation where existing modules are evaluated as to the requirements of the Regulation when the site is part of a common EU network.

The main goal of this study is to develop a methodology for assessing investment needs in line with the requirements of Regulation EU 2016/631. To achieve this goal, we perform the following actions:

1. Assessment of the adequacy of modules for the requirements of Regulation EU 2016/631;

2. Cost-benefit analysis (CBA) for existing installations;

3. Assessment of the investment needs of modules.

\section{METHODOLOGY AND MODELS}

A cost-benefit analysis is a process that businesses use to analyse decisions. The business or analyst sums the benefits of a situation or action and then subtracts the costs associated with taking that action. Some consultants or analysts also build models to assign a money value on intangible items, such as the benefits and costs associated with living in a certain town [12].

The economic analysis has been carried out by an additional cost method, comparing the two project implementation scenarios: the situation without the project and the situation with the project and taking into account only the additional costs and ben- efits associated with the implementation of the project. According to the CBA Regulation, the following performance indicators may be used: net present value; internal rate of profitability; rate of return; investment payback period. The algorithm uses performance indicators and criteria consistent with the Regulation [13] and the CBA guidelines for the EU investment projects [14], [15]:

- Economic net present value (ENPV): this must be greater than zero in a project that is desirable from an economic point of view;

- Economic rate of return (ERR): this 
should be higher than the social discount rate;

- Benefit-cost ratio $(\mathrm{B} / \mathrm{C})$ : this must be greater than one.

The sensitivity analysis is designed to identify the critical variables of the project that are used in drawing up the cash flow of the CBA. According to the guidelines, it is recommended to consider "critical" variables whose changes (positive or negative) by $1 \%$ of the basic value of the net present value are changed by $5 \%$. The calculation of limit values may reveal useful information, indicating at what percentage changes the net present value (economic or financial) is zero. The sensitivity analysis indicators are as follows: investment cost changes; full off (blackout) one event duration; number of full off (blackout) events per year.

The CBA has to be carried out for the reference period, or for the life cycle of the project, starting with the beginning of the project. The reference period or life cycle is the useful lifetime of the fixed assets created under the project, or the economically valid period of the project, during which it is possible to benefit financially or economically from the funds invested in the project or the assets created. The recommended length of the project life cycle in the energy sector is 25 years [16], [17], the reference period recommended by the European Commission in the energy sector is $15-25$ years (Table 1 ) [18], [19].

Table 1. Input Data

\begin{tabular}{|c|c|}
\hline Parameter & Input data \\
\hline Household losses & Not taken into account, no representative study \\
\hline Economic benefits & Annual value of avoided blackout \\
\hline Economic costs & $\begin{array}{c}\text { Capacity reservation fee } \\
\text { Spare capacity x (calendar number of hours per year) } \\
\text { x (Nord Pool Spot minus variable costs) }\end{array}$ \\
\hline Discount rate (real) & $5 \%$ \\
\hline Assessment period & 15 years \\
\hline
\end{tabular}

In order to determine the financial effectiveness of applying legal norms to existing electrical equipment, electricity generation modules will be considered as electrical equipment within this study. For each module, a number of points following which the relevant model is assessed should be provided for. In the course of the study, a methodology is developed to assess the conformity of models with the requirements of the Regulation, the necessary investments, and losses.

Two types of modules are distinguished: synchronous and park modules. The synchronous electricity generation module (SEGM) is an indivisible set of equipment capable of producing electricity in such a way that the ratio between the generated voltage frequency, the generator speed and the grid voltage frequency is constant and therefore these indicators are synchronous. An electricity park module (EPM) means an electricity generating unit connected to a network: (1) non-synchronic, (2) by means of an energy electronic (DC) converter, (3) connected to a high-voltage direct current system at a single termination point, (4) in different sets of such units. Each module is broken down to the type concerned, depending on the following active power (P) limits:

- Type A Module: $0.008 \mathrm{MW} \leq \mathrm{P}<$ $0.5 \mathrm{MW}$;

- Type B Module: $0.5 \mathrm{MW} \leq \mathrm{P}<5 \mathrm{MW}$;

- Type C Module: $5 \mathrm{MW} \leq \mathrm{P}<15 \mathrm{MW}$;

- Type D Module: $\mathrm{P} \geq 15 \mathrm{MW}$ or connection to power mains of $110 \mathrm{kV}$ or a higher voltage. 
The assessment is carried out according to the methodology in Fig. 1. For each module, its type is defined as SEGM or EPM, its active power and its conformity with type A, B, C or D have to be evaluated. By module breakdown, the requirements of the Regulation have to be structured and the conformity of each type with these has to be evaluated. As a result, a list of the requirements of the Regulation is drawn up. Each SEGM/EPM type and each A/B/C/D type of module are evaluated according to the applicable requirements (task No. 1). If the model complies with all the requirements of the Regulation, it is not taken into account in the subsequent calculations, this kind of breakdown is applicable as it is possible for their further assessment to be carried out by the CBA (Task No. 2). If the model does not meet a requirement, a technical-financial assessment has to be carried out for each requirement that the model does not meet when determining the required financial contribution (Task No. 3). In order to assess the efficiency of investments, the losses caused to the economy in an emergency situation and the impact on market development and the integration of renewable sources are assessed, depending on a number of safety aspects, namely: frequency, duration, and impact.

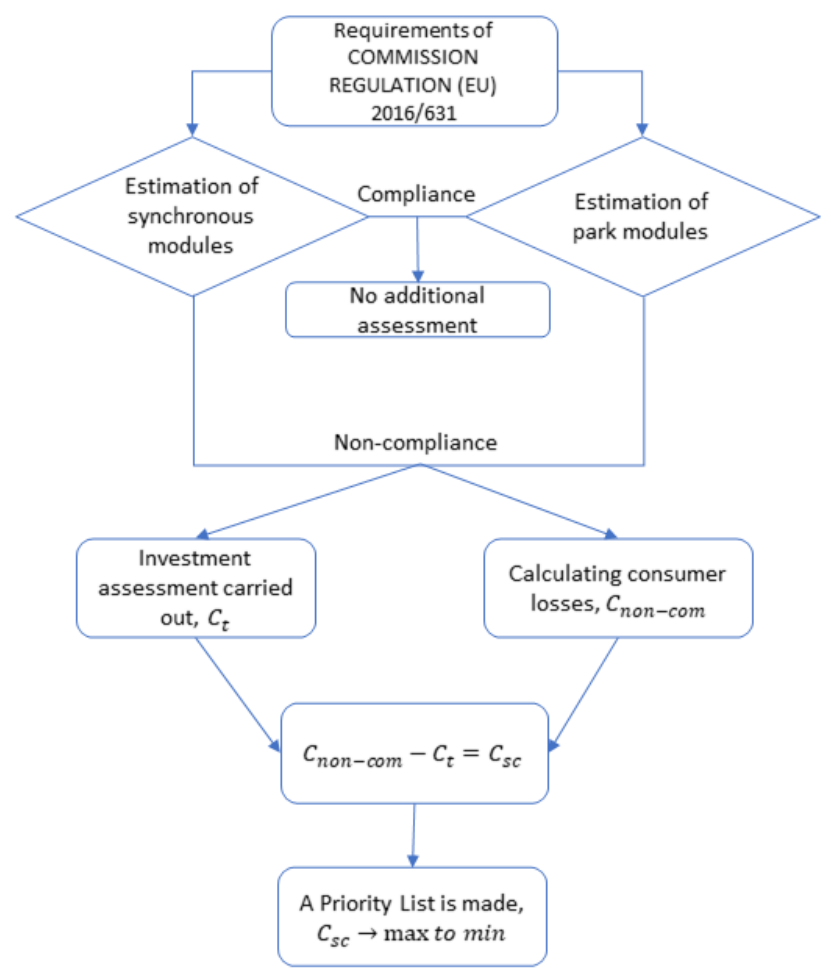

Fig. 1. Structure of the methodology developed.

In order to determine the assessment of the CBA and the investment needs (Figs. 2 and 3 ), it is necessary to define the objective function - maximising the state costs (Csc).

In order to achieve the objective set in the first phase, an investigation into Regulation 2016/631 has to be carried out; each requirement of the Regulation has to be evaluated, and a list of models of types $\mathrm{A}, \mathrm{B}, \mathrm{C}$ and D that must comply with the 
requirements of the Regulation is drawn up. Two lists are created, for a war-type model, where the SEGM and EPM types are assessed separately. At this stage, the type of each model for each of the requirements of the Regulation has to be assessed as to whether the model complies with the requirement. If the model meets all the requirements of the Regulation, it does not have to be taken into account in the subsequent calculations. If the model fails to meet any one of the requirements, a technical-financial assessment has to be carried out in the second phase.

If the results of the technical analysis of the system demonstrate a mandatory need for the technical development of the installations of the system, the need for investment is inevitable. In such a case, the issue lies in investment financing solutions. Given that electric power supply system members are economic operators, investments inevitably affect the financial performance of their activities. This means that investments must be able to ensure the financial efficiency of the project and the financial viability of the merchant. If the NPV of the project is negative, it is necessary to provide state aid.

On the other hand, if the results of the technical analysis of the system demonstrate alternative possibilities for the technical development of the installations of the system, the need for investment is justified by an economic analysis.

In the second phase, a module which does not meet a requirement of the Regulation has to undergo a financial and economic analysis. In accordance with the Regulation, an analysis is carried out, which determines the costs of ensuring compliance of the defined sites with specific requirements of the Connecting Code, the social and economic benefits resulting from the application of these requirements; cost-benefit performance indicators and the sensitivity of the project as a result of hypothetical fluctuations in its potential benefits and costs.

For each of the requirements of the Regulation, an estimate of the amount of investment required has to be made, taking into account the technological design and technical state of the existing electricity generation modules, which have to be determined on the basis of the information provided by their operators and the necessary replacement of existing installations or the setting up of additional new installations, as appropriate. The total required investment estimates for all synchronous and park modules of the type [A, B, C and D] concerned are determined on the basis of the information obtained on their number, capacity and existing technological installations used. On the basis of available information on the costs of the reconstruction of similar types and power plants over the past 10 years and assessing the non-compliance of production modules with the relevant requirements of the Regulation, the necessary investments for the implementation of each individual point are identified.

Many energy companies employ techniques that use the annual costs on the electrical grid:

$C_{t}=C_{K, t}+C_{E, t}$,

where

$C_{t}$ - annual cost in year $\mathrm{t}, \mathrm{EUR} / \mathrm{y} ; C_{K, t}-$ annual capital charge in year $\mathrm{t}, \mathrm{EUR} / \mathrm{y} ; C_{E, t}-$ operating costs in year $t, E U R / y$.

$C_{K, t}=\frac{i}{100} \sum_{j=1}^{m} K_{j}$,

where

$\sum_{j=1}^{m} K_{j}-$ total capital investments, EUR; $i$ - an interest rate, $\% ; m$ - the amount of investment from the beginning of the calculation period to year $\mathrm{T}$. 
The operating costs consist of two parts:

$C_{E, t}=C_{E k, t}+C_{E m, t}$,

where

$C_{E k t}$ - constant (load-independent) operating costs in year $\mathrm{t}$; $C_{E m, t}$ - annual operating costs of the variable (load-dependent) $t$, EUR/y; variable (load-dependent) operating costs in year $\mathrm{t}, \mathrm{EUR} / \mathrm{y}$.

The constant operating costs consist of the depreciation costs of the equipment and the costs of servicing and maintaining (repairing) the equipment:

$C_{E k, t}=\sum_{j=1}^{m} K_{j} * p_{a} / 100+\sum_{j=1}^{m} K_{j} * p / 100+C_{0}$,

where

$p_{a}-$ depreciation interest, $\% ; \mathrm{p}$ - interest on servicing and maintenance costs, \%; $C_{0}-$ rent, taxes, and other constant annual expenses.

The variable (load-dependent) operating costs consist of the cost of power and electric power losses in transformers and lines:

$C_{E m, t}=C_{\Delta P_{L}}+C_{\Delta P_{t g}}+C_{R}$

$C_{E m, t}=\sum \Delta P_{L}\left(\tau \beta^{\prime}+\beta^{\prime \prime}\right)+\sum\left(\Delta P_{t g}\left(T \beta^{\prime}+\beta^{\prime \prime}\right)+\Delta P_{v}\left(\frac{S_{m a k s}}{S_{N T}}\right)^{2} *\left(\tau \beta^{\prime}+\beta^{\prime \prime}\right)\right)+C_{R}$,

where

$C_{R}$ - costs of reliability of electric power supply, EUR/y, $\Delta P_{L}-$ power losses in the line, $\beta^{\prime}$ - electricity loss costs, $\beta^{\prime \prime}-$ power loss costs, $\Delta P_{t g}-$ load-independent idling loss, $\Delta P_{v}-$ load-dependent short-circuit losses, $T$ - transformer connection time, h/y; $\tau$ - maximum loss hours per year, h/y; $S_{m a k s}-$ transformer peak load, kVA; $S_{N T}-$ nominal power of transformers, kVA.

The annual costs for selecting project options can be used in two ways:

1. When calculating the net present value for the estimate period:

$N P V=\sum_{t=1}^{T} C_{t} * d_{t}$,

where

$d_{t}-$ a discount rate; $T-$ a calculation period in years.

The optimal option is selected at the minimum discounted annual cost $(\mathrm{NPV}=$ $\min )$.

2. By determining in advance the estimation level (for loads, loss costs, investments, etc.) at which the annual expenditure is calculated. Determining the equivalent level of the $\theta$ of the estimated years, it is necessary to take into account changes in load and cost veracity at the time (discounting factor and inflation), and the equivalence of static and dynamic criteria:

$C_{\theta} \sum_{t=1}^{T} d_{t}=\sum_{t=1}^{T} C_{t} * d_{t}$,

where

$C_{\theta}$ - annual cost estimates per year. The optimal option is selected at a minimum annual estimated $\operatorname{cost} C_{\theta}$ per year.

The second project option can be selected if no new objects appear during the estimate period. The first project option is more universal, without the limitations that are characteristic of the second project option but it is more labour-intensive, it should be carried out using the relevant computer programs, such as LDM-V and LDM-VZ. 
According to the guidelines of the ENTSO-E (European Network of Transmission System Operators for Electricity), the calculation of the benefits is carried out by calculating the total costs of avoid- ing total regional power outages. The costs are calculated using non-delivered energy, which depends on the average hourly consumption rate, the value of lost loads and the duration of the break [20]:

Non - delivered electricity costs $=$ VOLL $*$ consumption $*$ duration,

where

non-delivered electricity costs are measured in EUR, VOLL - in EUR/MWh; consumption in $M W h / h$, duration - in $h$.

Value of Lost Load. The determination of the VOLL depends on the level of customer differentiation determined by the depth of the study. It should be noted that there is no uniform size for all European countries, it differs significantly from country to country, which is due to a number of factors.

On the basis of the impact assessment criteria, the potential socio-economic benefits of the production module have to be determined for each point of the Regulation for which the model does not correspond (prevention of consumer losses) to $\mathrm{C}_{\text {non-com }}$ [EUR/15 years] during the period considered, which has to be determined by the following formula:

$C_{\text {non-com }}=\frac{\left(N^{a} * M^{b} * S^{c}\right)}{N^{a \max } * M^{b \max } * S^{c m a x} * 10^{3}} * P_{N} * T_{\max } * V * n_{a}$

where

$N$ - the probability factor (assumed at 10). In the case of Latvia, it is 10, in other power systems it may be determined differently depending on the amount of losses caused by the frequency of interruption of power supply; $a$ - the probability level of the effect: low (value 1) less than once every 10 years; average (value 2) - once a year; high (value 3 (a max)) - more frequently than once a year); $M$ - an impact scale factor (assumed to be 10 ); $b$ - an impact scale step: local (value 1) - single substations where production is connected module within borders; regional (value 2) - within the limits of one substation and adjacent substations; national (value 3 (b max)) - impact throughout the territory of Latvia; $S$ - an impact factor (assumed to be 10); $c$ - the degree of importance of impact (minor (value 1) - consumers cause interference in the electricity grid but their equipment continues to operate; essential (value 2): consumer operation is disrupted or temporarily terminated, no complete suspension and launch of equipment is required; critical/distinguished (value 3 (c max)): consumer operation is fully suspended and the period of $4 \mathrm{~h}$ or more is required for renewal; $P_{N}-$ nominal active power of the production module, or group of modules, under consideration, MW; $T_{\max }$ - the largest number of hours of operation on average in one year, over the past five years; $V$ - the cost of one unit of energy not delivered to consumers, EUR/MWh; $n_{a}-$ the period considered in years (15 years assumed). The period considered is adopted on the basis of practical data, where every 15 years there is a need for modernisation, reconstruction or other significant changes in activity or investment. 
The coefficients $\mathrm{M}, \mathrm{N}$ and $\mathrm{S}$ are assumed to be 10 as the maximum possible coefficient value. The possible value of the factor is between 0 and 10. The ratios are assumed to be 10 , as equipment can have a significant impact on the overall functioning of the system as a result of various events. In the assumptions, the ratio 10 is based on the impact of the criterion: 10 - the largest impact, 0 - no impact. The criteria breakdown from 0 to 10 is taken into account on the basis of risk analysis carried out during the modelling process.

In the third phase, after the calculations have been made, for each clause of the Regulation which does not correspond to the model there is a comparison between investment costs $\left(C_{\text {invest }}\right)$ and noncompliance costs $\left(C_{\text {non-com }}\right)$ (task No. 3). This results in a value $\left(C_{s c}\right)$ that shows how valuable the model is, as well as whether the socio-economic benefits are obtained by reconstructing the model:

$C_{\text {non-com }}-C_{\text {invest }}=C_{\text {st }}$.

The evaluation and calculation of all the points of the Regulations for all models have to result in the drawing up of a list of models, starting with the largest Csc models, in order of priority. Such a list is capable of more objectively assessing and identifying which models require investment primarily in order to optimise electricity infrastructure and optimal investment.

\section{RESULTS BASED ON THE EXAMPLE OF LATVIA}

As part of the study, the use of methodologies for Latvian modules is developed. In accordance with the requirements of the Regulation, all the generating sources installed in Latvia and connected to the power grid, with a capacity exceeding $0.8 \mathrm{~kW}$, are covered within the scope of the study.

The study uses abstract, plant-classappropriate, standard equipment parameters and economic performance indicators of merchants, as well as available secondary data.

Information on generating sources is obtained both directly from their operators when they receive replies to the information request questionnaires and from the information previously received by the transmission system operator as well as from the publicly available database of the Central Statistical Bureau (CSB).

Given that, by the deadline set for the completion of the study, no information was received from a large number of the producers whereas the total number and capacity of the production plants were known, the output data were extended to all the producers, since the introduction of a requirement of the Regulation would affect all electricity generators and consumers, the related costs and benefits.

Also, taking into account the restrained attitudes of the owners of several production modules towards the provision of output data, for a number of parameters for which no accurate reports or complete questionnaires were received, the output data required within the study were calculated on the basis of similar reporting data from similar power plants as well as the data collected by the Central Statistical Bureau of Latvia and other studies on the techno-economic performance of capacity operations within electricity generation. On the basis of studies [21]- [24], approximate estimates were made for different types of production modules in addition to operating costs resulting from the introduction of the requirements of the Regulation.

The study is based on input data 
received for the current situation for 2020, assuming that the Regulation has been applied to all power plants put into service after 31 December 2018 (taking into account the transitional rules laid down in the Regulation).
A summary of information on EGMs (electricity generation modules) based on data received and calculated can be found in Table 2. Since each generation source is considered to be a separate module, it is not detailed in the article in the context of sensitive information.

Table 2. Electricity Generation Modules

\begin{tabular}{|c|c|c|c|c|c|c|}
\hline $\begin{array}{l}\text { Type of } \\
\text { module }\end{array}$ & $\begin{array}{c}\text { Number } \\
\text { of units, } \\
\text { pcs. }\end{array}$ & $\begin{array}{c}\text { Total } \\
\text { installed } \\
\text { capacity, } \\
\text { MW }\end{array}$ & $\begin{array}{c}\text { Total annual } \\
\text { electricity } \\
\text { output, GWh }\end{array}$ & $\begin{array}{l}\text { Income foregone } \\
\text { for electric } \\
\text { power unit after } \\
\text { implementation } \\
\text { of the require- } \\
\text { ment, EUR/ } \\
\text { MWh }\end{array}$ & $\begin{array}{l}\text { Additional } \\
\text { variable costs } \\
\text { assumed for the } \\
\text { electric power } \\
\text { unit following } \\
\text { the implemen- } \\
\text { tation of the } \\
\text { requirement, } \\
\text { EUR/MWh }\end{array}$ & $\begin{array}{l}\text { Fixed addi- } \\
\text { tional costs per } \\
\text { module after the } \\
\text { implementation } \\
\text { of the require- } \\
\text { ment, EUR/ } \\
\text { module per year }\end{array}$ \\
\hline \multicolumn{7}{|c|}{$\begin{array}{l}\text { Synchronous } \\
\text { modules }\end{array}$} \\
\hline A-type & 46 & 12 & 68 & 10.00 & 0.90 & 400.00 \\
\hline B-type & 119 & 187 & 1187 & 10.00 & 0.90 & 600.00 \\
\hline C-type & 1 & 6.3 & 31 & 10.00 & 0.12 & 900.00 \\
\hline D-type & 37 & 2636.30 & 5680.35 & 10.00 & 0.05 & 1500.00 \\
\hline \multicolumn{7}{|c|}{ Park modules } \\
\hline A-type & 282 & 50.80 & 90.60 & 10.00 & 1.00 & 400.00 \\
\hline B-type & 20 & 33.40 & 58 & 10.00 & 1.00 & 600.00 \\
\hline C-type & 1 & 6.90 & 10.80 & 10.00 & 0.18 & 900.00 \\
\hline D-type & 1 & 20.7 & 32.40 & 10.00 & 0.15 & 1500.00 \\
\hline
\end{tabular}

Given that no major new production modules are currently being launched and no plans are in place, if certain low-capacity production modules are introduced, they will play a minor role. In order to ensure stability for the power supply system, it is necessary to apply part of the requirement referred to in the Regulation to the synchronous production modules for Type D production, provided that these requirements do not require inadequate investments (the conversion of primary energy carriers to electric energy and/or the conversion of the power part of generators), provided that these production modules continue to operate long enough after the year 2025 (five and more years). Existing Type D synchronous production modules represent $89 \%$ of the total installed capacity.

On the other hand, the production synchronous modules of types A, B, C and D as well as park modules of types A, B, C and $D$ represent a relatively small part of the power supply system (approximately $11 \%$ of the installed capacity: $320 \mathrm{MW}$ ), but their large number (several hundred) poses a risk that their administration might be technically complex and labour inten- 
sive, as well as the implementation of the requirements is technically disproportionately complex and therefore the introduction of the requirements of the Regulation for these production modules (existing electrical equipment) is not socio-economically justified. In addition, it should be noted that there is a reduction in capacity in this module segment (closure of modules) due to the government policy of the Republic of Latvia to minimise the production of subsidised electricity (in order to minimise electricity tariffs), particularly in view of the fact that state aid has been fixed for a period of 10 to 20 years and a moratorium on the granting of new rights has been established since 2012 [25].

Consequently, when deciding on the modernisation of existing power plants (rebuilding in line with the requirements of the RfG (Commission Regulation (EU) 2016/631 of 14 April 2016), it should also be taken into account whether improvements are justified for the remainder of plant lifetime.

In addition, it should be noted that a large proportion of these producers work according to the schedules of heat load schedules (combined heat and power plants); available water resources (hydropower plants, $29 \mathrm{MW}$ ) or wind (wind power plants, $\sim 78 \mathrm{MW}$ ), which means that a large part of these production modules are not permanent and their adaptation to the stability of the system is technically difficult.

Although the reporting data show that during the summer months the synchronous and park modules of types A, B and $\mathrm{C}$ represent a relatively large proportion of generation, even for a relatively long proportion from the hours of the day, the consumption needs in these periods are mainly met by imported electricity from sources outside Latvia. Consequently, the benefits of applying the RfG requirements to modules of types A, B and C are not relevant during these periods (Table 3 ).

Table 3. Costs of Existing Electricity Generation Modules and their Socio-Economic Effect over 15 Years, if the Requirements of the Regulation are Introduced

\begin{tabular}{|l|l|c|c|}
\hline \multicolumn{2}{|l|}{$\begin{array}{l}\text { Type of electricity generation } \\
\text { modules }\end{array}$} & $\begin{array}{c}\text { Costs of implementing RfG } \\
\text { over 15 years, } \\
\text { in EUR million }\end{array}$ & $\begin{array}{c}\text { Social benefits of applying the require- } \\
\text { ments of the RfG over 15 years, in } \\
\text { EUR million }\end{array}$ \\
\hline \multirow{4}{*}{$\begin{array}{l}\text { Synchronous } \\
\text { modules }\end{array}$} & A-type & 3.93 & 4.82 \\
\cline { 2 - 4 } & B-type & 34.37 & 161.43 \\
\cline { 2 - 4 } & C-type & 0.67 & 15.43 \\
\cline { 2 - 4 } & D-type & 106.61 & 3681.10 \\
\hline \multirow{5}{*}{ Park modules } & A-type & 22.68 & 8.44 \\
\cline { 2 - 4 } & B-type & 9.88 & 11.04 \\
\cline { 2 - 4 } & C-type & 1.18 & 4.53 \\
\cline { 2 - 4 } & D-type & 2.32 & 18.66 \\
\hline
\end{tabular}

Comparing the costs of the introduction of the RfG (investment and operational) to existing electricity generation modules (EEGM) over a period of 15 years with the socio-economic benefits of society, the benefits of all EEGM, excluding type A park modules, exceed the costs (Table 4). 
Table 4. Investments Needed to Ensure the Eligibility of D-type Modules in EUR (thousands)

\begin{tabular}{|l|c|c|}
\hline Number of aggregates (SM)/Modules (PM): & $\begin{array}{c}\text { D-type synchronous } \\
\text { modules } \\
\mathrm{P} \geq 15 \mathrm{MW} \text { or } 110 \mathrm{kV} \\
\text { connection }\end{array}$ & $\begin{array}{c}\text { D-type park } \\
\text { modules } \\
\text { connection }\end{array}$ \\
\hline Number of aggregates (SM)/Modules (PM) & 37 & 1 \\
\hline Total installed capacity (MW) & 2636.30 & 20.70 \\
\hline Necessary investments & 12063.50 & 461.19 \\
\hline F - Frequently defined active power response & 1436.26 & 18.70 \\
\hline B - Balancing reserves & 6032.20 & 49.86 \\
\hline Supply of R - jet power: & 35.50 & 12.46 \\
\hline P- Overload control & 76227.19 & 1520.81 \\
\hline a - Protection measures & 4462.30 & 152.11 \\
\hline Category C - other & 100256.95 & 2215.13 \\
\hline Total: & & \\
\hline
\end{tabular}

\section{DISCUSSION}

In theory, there are a number of technical alternatives (Table 5), the implementation of which would ensure stability for the power supply system. Each of these alternatives requires both investment and state funding for their maintenance and there are different risks for both their disposal and operation. These risks are both legal and related to the creation of a partly regulated market with an extremely limited range of competitors, a possible monopoly position with only one supplier participating.

Below follows a list of potential alternatives for solutions which, by applying the Regulation to the limitations and socio-economic benefits of existing electricity generation modules, will ensure that the objectives set out in the Regulation are achieved. In order to ensure the stability of the system, modules are allocated according to capacity and impact on the functioning of the whole system. According to the authors' estima- tion, the planned capacity demand was calculated on the basis of potential deficit.

Alternative A: Modernisation of Type D synchronous modules ("Big", with a power of $15 \mathrm{MW}$ or with a connection to a network of $110 \mathrm{kV}$ or more); inefficient operation of power plants (irrespective of the timetable for heat load schedules and stock market prices for combined heat and power generation units of $220 \mathrm{MW} ; 1280 \mathrm{~h} /$ year and/or regardless of market prices for hydroelectric power plants); in this case, modernisation would mean the implementation of the requirements of the Regulation, and in addition to ensuring stability for the system, it would be necessary to maintain switched production modules in such modes as to guarantee capacity reserves (primary frequency adjustment (retention) reserves) FCR of +/-10 MW and (automatic frequency renewal reserves) aFRR of +/-30 MW [information from TSOs]. It 
should be noted that investment is assumed to be implemented in all synchronous modules, but it is likely that these investments may be significantly reduced if one of the existing modules ceases to operate or is fully rebuilt and loses its "existing electrical equipment" status.

In addition, it should be noted that this is the only alternative, which can provide all the necessary technical functions for sound operation of the power supply system.

Alternative B: Construction of a "new" internal combustion engine power plant 12 × $8 \mathrm{MW}=96 \mathrm{MW}$. Operating $12 \mathrm{MW}$ + $36 \mathrm{MW} 1280 \mathrm{~h} /$ year regardless of stock market prices; investments of 0.5 MEUR/ MW [26]; 96 x 500 = 48 MEUR; fixed operating costs of $15 \mathrm{EUR} / \mathrm{kW} /$ year and variable costs of $0.5 \mathrm{EUR} / \mathrm{kWh}$ [26], which in our case means investment of 48 MEUR and operating costs. This alternative has a number of technical limitations, which do not allow it to be considered as a fully-fledged alternative: (1) a limited operating hour resource of the power plant, which does not permit permanent operation of such a type of power plant; (2) this power plant has to be used as a "cold" reserve, so that it can only provide functions which allow for the supply of additional active power to the electrical power system for five minutes or more within minutes.

Alternative C: Installation of highcapacity batteries; taking into account the permitted discharge levels and reservations of electrochemical batteries, it is estimated that a battery with a capacity of $45 \mathrm{MWh}$ is required for FCR +/-10 MW; an aFRR $+/-30 \mathrm{MW}$ battery of $130 \mathrm{MWh}$ is required to provide an aFRR of $+/-30 \mathrm{MW}$. Estimated cost of construction of the above batteries: 14.248 MEUR and 41.924 MEUR, total 56.172 MEUR. The estimated operat- ing costs are related to energy losses and servicing: FCR of 162767.10 EUR/year and aFRR of 310400.44 EUR/year. Due to the ageing of battery cells, they should be replaced once in every approximately 2000 full cycles of charge/discharge, which would be every 15 years in the case of FCR and would cost 4.5 MEUR; in the case of aFRR the replacement time would be every 7.5 years and the cost would be 13 MEUR. Nor is this alternative capable of fulfilling all the functions provided by synchronous Type D modules and therefore is not considered to be technically equivalent.

Alternative D: Installation of highcapacity batteries and controlled (harmonised) consumer switching through an aggregate service. As part of this solution, it would be possible to reduce the number of battery charge/discharge cycles per unit of time and thus increase the length of the battery cell replacement interval. As part of this study, it is assumed that such a solution would allow the intervals to be increased twice, respectively, in the case of FCR to 30 years and in case of aFRR to 15 years. This option assumes that half of the charge/discharge energy will be "absorbed" (increased load) and "returned" (reduced load) by consumers. The energy costs would be EUR 80.00/MWh in such a case. There would also be an additional payment for the delegated load of EUR 10.00/MW. The calculations show that this alternative becomes economically competitive when it is possible to "take" and "return" electricity from consumers, at a price close to the average market price of EUR 40.00. This alternative is also incapable of fulfilling all the functions provided by synchronous Type D modules and is therefore not considered to be technically equivalent (Table 5). 
Table 5. Technical Alternatives that would Ensure Stability for the Power Supply System

\begin{tabular}{|c|c|c|c|c|}
\hline Alternative & $\begin{array}{c}\text { Technical solu- } \\
\text { tion }\end{array}$ & $\begin{array}{c}\text { Investment } \\
\text { costs } \\
\text { (million EUR) }\end{array}$ & $\begin{array}{c}\text { Additional } \\
\text { operating } \\
\text { costs per year } \\
\text { (million EUR) }\end{array}$ & Risks \\
\hline A. & $\begin{array}{l}\text { Modernisation of } \\
\text { Type D synchro- } \\
\text { nous modules } \\
\text { (with a capac- } \\
\text { ity of } 15 \mathrm{MW} \\
\text { or connections } \\
\text { of } 110 \mathrm{kV} \text { and } \\
\text { above); operation } \\
\text { of power plants } \\
\text { in inefficient } \\
\text { mode ( } 220 \mathrm{MW} \text {; } \\
1280 \mathrm{~h} / \text { year) }\end{array}$ & 100.26 & 3.04 & $\begin{array}{l}\text { 1. In view of the existence of two such } \\
\text { production modules and the need } \\
\text { for maintenance on a regular basis, } \\
\text { there is a risk that there will be only } \\
\text { one production module operating for } \\
\text { approximately } 720 \text { hours a year, which } \\
\text { may participate in frequency adjust- } \\
\text { ment and, in the event of failure, the } \\
\text { system may remain without frequency } \\
\text { adjustment (n-1 security factor) } \\
\text { There is a risk that there will be insuf- } \\
\text { ficient competition in the frequency } \\
\text { regulating market }\end{array}$ \\
\hline B.* & $\begin{array}{l}\text { Construction of } \\
\text { a "new" internal } \\
\text { combustion } \\
\text { engine power } \\
\text { plant } \\
12 \times 8 \mathrm{MW}= \\
96 \mathrm{MW} \\
(12 \mathrm{MW}+ \\
36 \mathrm{MW}, 1280 \mathrm{~h})\end{array}$ & 48.00 & 2.36 & $\begin{array}{l}\text { 1. There is a risk that there will be insuf- } \\
\text { ficient competition in the frequency } \\
\text { regulating market, although this will } \\
\text { be less than in the case of A } \\
\text { 2. A substantial increase in the costs of } \\
\text { building a power plant may be pos- } \\
\text { sible, which can only be determined } \\
\text { more precisely after defining the } \\
\text { parameters of the decal and selecting a } \\
\text { specific location }\end{array}$ \\
\hline C.* & $\begin{array}{l}\text { Installation of } \\
\text { high-capacity bat- } \\
\text { teries }\end{array}$ & 56.17 & $2.48(0.47)^{*}$ & $\begin{array}{l}\text { 1. There is a risk that there will be insuf- } \\
\text { ficient competition in the frequency } \\
\text { regulating market, although this will } \\
\text { be less than in the case of A }\end{array}$ \\
\hline D.* & $\begin{array}{l}\text { Installation of } \\
\text { high-capacity } \\
\text { batteries and } \\
\text { establishment of } \\
\text { a demand unit }\end{array}$ & 58.17 & $3.29(1.86)^{* *}$ & $\begin{array}{l}\text { 1. Organisational and legal risks: it may } \\
\text { not be possible for a sufficiently large } \\
\text { consumer to view and agree on the } \\
\text { necessary investments and on a pattern } \\
\text { of cooperation within a reasonable } \\
\text { period of time } \\
\text { 2. Technical risks: a new, relatively large, } \\
\text { and complex system must be devel- } \\
\text { oped, which has not yet been accred- } \\
\text { ited under the conditions of Latvia }\end{array}$ \\
\hline
\end{tabular}

* - Alternatives B, C, and D cannot be considered to be technically equivalent as they cannot technically meet the requirements of Type $\mathrm{D}$ synchronous modules set out in the Regulation

** - Costs exclusive of replacement of battery cells 1 x 15 years (FCR) and 1 x 7.5 years (aFRR)

$* * *$ - Costs exclusive of replacement of battery cells 1 x 30 years (FCR) and 1 x 7.5 years (aFRR) 
In the example of Latvia, it is necessary to carry out a quantitative study on the application of the RfG provisions only for the modernisation of existing Type D synchronous production modules, while also examining alternatives $\mathrm{B}, \mathrm{C}$ and $\mathrm{D}$ as an additional technical means of improving the reliability of power supply. The consideration of alternatives is also desirable given that Type D synchronous modules operate on heat load schedules (combined heat and power plants) or available water resources (hydropower plants), and taking into account the market situation on the electricity exchange (hydropower and combined heat and power generation units in condensation mode or with heat batteries), the continuous operation of these modules involves additional costs or is even technically limited.

Alternatives B, C, D should be used to supplement certain functions to apply the requirements of Type $\mathrm{D}$ synchronous production modules for RfG, or additional measures should be included to ensure the stability of the power supply system.

\section{5, CONCLUSIONS}

The developed methodology is to help to assess the need for investment in line with the requirements of Regulation (EU) 2016/631. It is assessed by type SEGM or EPM and by type A, B, C or D as regards the active power and its type. This methodology provides the possibility to make the necessary investments in ERM in higher quality and with greater economic benefits, by grouping them according to the effectiveness of the return on investments.

In the case of Latvia, the application of the requirements of the Regulation to Type D synchronous electricity generation modules is socio-economically justified. For other types of production modules, the introduction of the requirements of the Regulation in socio-economic terms is not justified, due to their relatively small impact on the electric power supply system and, in addition, their expected mass decommissioning, which will make the share of these modules even less relevant in the overall producer capacity balance sheet and reduce the expected socio-economic benefits (reducing the efficiency of investments in the RfG). Therefore, in accordance with Article 4 of the Regulation, it is recommended that a thorough and transparent quantitative cost-benefit analysis be carried out in accordance with Articles 38 and 39 of the Regulation for synchronous production modules of Type D.

\section{ACKNOWLEDGEMENTS}

The research has been supported by the National Research Programme, project "Trends, Challenges and Solutions of Latvian Gas Infrastructure Development" (LAGAS) (No. VPP-EMINFRA-2018/1-0003).
The research has been supported by the Latvian Council of Science "Management and Operation of an Intelligent Power System (I-POWER)" project No. 1zp-2018/10066. 


\section{REFERENCES}

1. Zemite, L., Gerhards, J., Gorobetz, M., \& Levchenkov, A. (2015). Optimization of distribution systems reliability with the stochastic behavior. In 56th International Scientific Conference on Power and Electrical Engineering of Riga Technical University, 14 October 2015, Riga, Latvia. 7343172. doi: 10.1109/RTUCON.2015. 7343172, 2015.

2. Kutjuns, A., \& Zemite L. (2009). Power network system reliability and methods of calculation. In IEEE Bucharest PowerTech Conference "Innovative Ideas toward the Electrical Grid of the Future", (pp. 360266), 28 June-2 July 2009, Bucharest, Romania, 5282066.

3. Zemite, L., Kutjuns, A., Bode, I., Kunickis, M., \& Zeltins, N. (2018). Risk Treatment and System Recovery Analysis of Gas System of Gas and Electricity Network of Latvia. Latvian Journal of Physics and Technical Sciences, 55 (5), 3-14. doi: 10.2478/lpts-2018-0031.

4. Kutjuns, A., Kovalenko, S., Zemite, L., \& Žbanovs, A. (2018). Analysis of faults impact on gas and electricity systems. In 19th International Scientific Conference on Electric Power Engineering, EPE, (pp. 1-5), 16-18 May 2018, Brno, Czech Republic. doi: 10.1109/EPE.2018.8395961.

5. Group Expert. (2018). Cost Benefit Analyses ENTSO-E Guidance Document for National Implementation for Network Codes on Grid Connection. ENTSO-E AISBL, Brussels, Belgium.

6. AST. (n.d.). Sistēmas regulēšana. Available at https://www.ast.lv/lv/content/sistemasregulesana.

7. Ministry of Economics. (2019). MK apstiprina virzību uz Latvijas elektrotīklu sinhronizāciju ar Eiropas elektroenerǵijas sistēmu 2025. gadā. Available at https:// www.mk.gov.1v/lv/aktualitates/mkapstiprina-virzibu-uz-latvijas-elektrotiklusinhronizaciju-ar-eiropas
8. AST. (n.d.). Sinhronizācija ar Eiropu. Available at https://www.ast.lv/lv/projects/ sinhronizacija-ar-eiropu

9. Kurevska, L., Sauhats, A., Junghans, G., \& Lavrinovcs, V. (2019). Harmonization of imbalance settlement period across Europe: The curious case of Baltic energy markets. In IEEE 60th Annual International Scientific Conference on Power and Electrical Engineering of Riga Technical University, 7-9 October 2019, Riga, Latvia, 8982334. doi: 10.1109/ RTUCON48111.2019.8982334.

10. Kurevska, L., Sile, T., \& Sauhats, A. (2019). Developing an economically advantageous wind forecasting method for electricity market design with a 15-minute imbalance settlement period. In International Conference on the European Energy Market, EEM, 18-20 September 2019, Ljubljana, Slovenia, 8916574. doi: 10.1109/ EEM.2019.8916574.

11. Marcina, K., Sauhats, A., Lavrinovics, V., \& Junghans, G. (2018). Efficiency analysis of the Baltic balancing market. In International Conference on the European Energy Market, EEM, 27-29June 2018, Lodz, Poland, 8469992. doi: 10.1109/ EEM.2018.8469992.

12. Investopedia. (n.d.). Cost-Benefit Analysis. Available at https://www.investopedia.com/ terms/c/cost-benefitanalysis.asp

13. Commission Regulation (EU) 2016/631 of 14 April 2016 establishing a network code on requirements for grid connection of generators. C/2016/2001. Available at Commission Regulation (EU) 2016/631 of 14 April 2016 establishing a network code on requirements for grid connection of generators

14. European Commission Directorate-General for Regional and Urban Policy. (2015). Guide to Cost-Benefit Analysis of Investment Projects. Economic appraisal tool for Cohesion Policy 2014-2020. Luxembourg: Publications Office of the European Union. 
15. Petrichenko, L., Sauhats, A., Petrichenko, R., \& Bezrukovs, D. Long-term price forecasting for the cost-benefit analysis of power equipment. In IEEE 59th Annual International Scientific Conference on Power and Electrical Engineering of Riga Technical University, RTUCON 2018, 12 13 November 2018, Riga, Latvia, 8659888. doi: 10.1109/RTUCON.2018.8659888.

16. Finanšu ministrijas Eiropas Savienības fondu uzraudzības departaments. (2011). Vadlīnijas atbildīgajām un sadarbības iestādèm Eiropas Savienības fondu projektu izmaksu efektivitātes novērtēšanas un izmaksuieguvumu analīzes pamatprincipi. Riga.

17. Komisijas regula (ES) 2016/1447 ar ko izveido tīkla kodeksu par tīkla pieslēguma prasībām, kuras piemērojamas augstsprieguma. Available at https://eur-lex. europa.eu/eli/reg/2016/1447/oj/?locale=LV

18. International Renewable Energy Agency. (2012). Renewable Energy Technologies: Cost Analysis Series, Wind Power I. Available at https://www.irena.org/-/media/ Files/IRENA/Agency/Publication/2012/ RE_Technologies_Cost_Analysis-WIND_ POWER.pdf
19. Ekodoma. (2013). Elektroenergijas, kas ražota no atjaunojamiem energoresursiem un kogenerācijā, atbalsta izvērtējums un priekšlikumi atbalsta uzlabošanai. Available at http://www.ekodoma.lv/sites/default/files/ publications/sia_ekodoma_atskaite.pdf

20. International Renewable Energy Agency. (2012). Renewable Energy Technologies: Cost Analysis Series. Hydropower. Available at https://www.irena.org/documentdownloads/ publications/re technologies_cost_analysishydropower.pdf

21. GmbH, KEMA Consulting. (2013). Technical Report on ENTSO-E Network Code: Requirements for Generators. Available at https://ec.europa.eu/energy/sites/ener/files/ documents/KEMA_Final\%20Report_RfG $\% 20$ NC.pdf

22. Helmane, I. (2016). Atjaunojamās energijas nozarei ierobežo peḷnu un apstādina OIK maksas kāpumu. Available athttps://lvportals. lv/skaidrojumi/280639-atjaunojamasenergijas-nozarei-ierobezo-pelnu-unapstadina-oik-maksas-kapumu-2016 